\title{
Labor Economics and Career Development in the Context of Globalized World
}

\author{
Zuzana Dvorakova ${ }^{1, *}$ \\ ${ }^{1}$ Czech Technical University in Prague, Faculty of Biomedical Engineering, nám. Sítná 3105, 27201 \\ Kladno, Czech Republic
}

\begin{abstract}
.
Research background: The paper uses labor economics and career theory to design an integrative approach to career research focusing on new occupations and career development.

Purpose of the article: The purpose of this paper is to call for an integrative approach to career research aiming to characterize labor market trends and discuss perspectives on careers using highly skilled migrants from Central and Eastern Europe as a case. The paper discusses the specificity of career development in the context of the Industry 4.0. and an integrative approach vs. other approaches.

Methods: The methodology insists on several ways that enable a triangular analysis. The research combines in-depth-analysis of bibliographic data in the Web of Science database, unstructured interviews with top managers/co-owners of multinational companies in August and September 2020 as a base for writing two narrative cases.

Findings \& Value added: Findings show the tendency of career theory to provide a narrow view of a career. They highlight the trends in considering the wide variety of career situations, which results from the fact that careers locate in time and space. The paper provides examples to explore career differences better and seek for alternative explanations to career experiences. Because career dynamics are influenced by individual characteristics and career development practices, a more integrative approach to career research must address the complexity of labor markets. The added value is to encourage discussions about career theory focusing on a wide range of issues.
\end{abstract}

Keywords: Labor economics; Occupations; Career; Career development

JEL Classification: $J 21 ; J 24 ; M 12$

*Corresponding author: zuzan.dvorak@gmail.com 


\section{Introduction}

In the context of Industry 4.0, labor force changes accelerate, and workers must adapt to the demands of the labor market if they want to keep their jobs and continue their careers. The economy creates jobs for all types of achieved education, but it is evident that the most remarkable growth in demand arises on workers who have completed secondary and higher education. Although new occupations will create, many existing jobs strongly influence technology, the international division of labor, and the workforce's growing education. These changes affect everyone, and few will have the same job throughout their productive lives, so most must improve or expand their skills, or even change their careers.

Nobody is sure what he/she can expect from structural changes in the labor market. Some trends predict what to count on and what to consider when deciding on future education and careers. Some jobs will exist, others will change, and others will disappear. Statistics and research studies about labor market developments in the context demographic changes are available; personnel/human resource experts discuss dividing labor into good and evil and estimate career development opportunities.

The purpose of this paper is to call for an integrative approach to career research aiming to characterize labor market trends and discuss perspectives on careers using highly skilled workers in multinational companies operating in the Czech Republic as cases. The paper discusses the specificity of career development in the context of Industry 4.0. and an integrative approach vs. other approaches.

\section{Research methods}

The methodology insists on several methods that enable a triangular analysis. The research combines state-of-the-art knowledge identified by in-depth-analysis of secondary sources, mainly papers from the Web of Science, and published in 2018-2020, with two unstructured interviews held with top managers/owners in August and September 2020. The interviews provide information for writing two narrative cases. The interviews concentrate on aspects identifying career development approaches in business and personnel/human resource practices used for achieving a sustainable career. The focus represents the following questions:

- What reasons motivate employees to change jobs or change their careers?

- What practices can effectively develop competencies?

- What personnel/human resource management is accepted by employees so that they are interested in developing their careers and not interested in leaving their employers.

The reasoning methods are that career touches human beings and deals with social phenomena, which is deeply rooted in history, culture, values, and behaviors. However, business reality tends to apply pragmatic practices. Secondly, based on the bibliometric analysis, a need for an integrated approach to developing a career is evident due to the world's uncertainty and dynamics in the labor markets. Therefore, research collects and analyses data by an interpretative group of methods that reveal human subjects' meaningmaking practices to get a basis for achieving results, emerging questions for the practice, and ideas for future research.

\section{Literature overviews}

\subsection{The bibliographic analysis}


We retrieved 120785 bibliographic records that matched the query in database search in the period 2000-2020. In the period 2000-2020, records from the Web of Science databases count for 46501 and Scopus 74 284, during 2018-2020, it is evident substantially growing interest in topics as shown in Table 1. The enormous amount of literature of various sciences does not allow a complete analysis of all of them. The analysis limits the most significant works in the paper, considering the citation index related to labor economics, employability, career theory, career development, and career sustainability from 2018 to 2020. The Web of Science studies outlines the development of promising directions in several areas, mostly in education and educational research, management, economics, applied psychology, and scientific education disciplines.

Table 1. Bibliographic records by the query in the Web of Science and Scopus databases.

\begin{tabular}{|c|c|c|c|c|}
\hline Query & $\begin{array}{c}\text { Web of Science } \\
\mathbf{2 0 0 0 - 2 0 2 0}\end{array}$ & $\begin{array}{c}\text { Web of Science } \\
\mathbf{2 0 1 8 - 2 0 2 0}\end{array}$ & $\begin{array}{c}\text { Scopus } \\
\mathbf{2 0 0 0 - 2 0 2 0}\end{array}$ & $\begin{array}{c}\text { Scopus } \\
\mathbf{2 0 1 8 - 2 0 2 0}\end{array}$ \\
\hline Labor economics & 5579 & 1303 & 16115 & 3387 \\
\hline Employability & 6176 & 2275 & 7574 & 2427 \\
\hline Career theory & 9622 & 2947 & 12049 & 3101 \\
\hline Career development & 23166 & 6654 & 35585 & 8168 \\
\hline Career sustainability & 768 & 308 & 1126 & 395 \\
\hline Sustainable career & 1190 & 485 & 1835 & 597 \\
\hline Total & 46501 & 13972 & 74284 & 18075 \\
\hline
\end{tabular}

Source: Author. Accessed 2020/09/29.

Labor economics belongs to the most studied topics in the USA (359 publications in the Web of Science in 2018-2020, accessed on 2020/09/30), England (135), Germany (105), Russia (91), Australia (73), and in the CR 18 ones. Articles cover according to categories topics from economics (509 publications), education and educational research (86), development studies (69), management (68), and environmental studies (54), and others.

In the case of employability, the order of the number of publications characterizes the following: England (403), Australia (278), Spain (241), the USA (192), and Netherlands (129). The CR records 22. Papers belong to topics from categories: education and educational research (1 055 publications), management (195), applied psychology (99), economics (96), and scientific education disciplines (80).

Publications about career theory mainly print in the USA (1 167), England (299), Australia (226), the People's Republic of China (220), and Canada (168), and the same period in the CR 13. They focus predominantly on education and educational research (596 publications), applied psychology (490), management (457), business (189), and scientific education disciplines (144).

Career development mostly becomes a subject of publications in the USA (2 370), England (672), Australia (489), the People's Republic of China (381), Canada (323), and Russia (286), but the CR 50. They belong to education and educational research (1 776), applied psychology (519), management (517), scientific education disciplines (446), public environmental and occupational health (261).

The focus on career sustainability predominately seen in papers published in the USA (94), Australia (40), England (39), Canada, the People's Republic of China, and Spain (each per 20), in the CR, only one. They go to green sustainable science technology (61), 
environmental sciences (60), education and educational research (55), environmental studies (53), and management (26).

\subsection{A theoretical ground of the career development}

Current labor markets characterize the shortage of talents, rising demands of technical skills, aging of the population, and disappearance of repetitive jobs. Competitiveness in the industrial sectors and the implementation of modern technologies make up specialists with the science, math, and engineering background of the critical labor force. Such employees feel stronger when negotiating employment conditions, and employers become weaker in their staffing and retaining. On the other side, the labor market requirements must match migrants' supply and unskilled or semi-skilled workers. For example, job growth in Germany, Spain, Sweden, and the UK in 1992-2015 is evident in occupations with high job quality characterized by education, prestige, and job satisfaction. That means production workers and office clerks lost grounds, and employment enormously expands in the salaried (upper) middle class among managers and professionals [1]. The speed of technological changes emerged in Industry 4.0 and created a significant gap between employees' current capability and job requirements. So, employers must rethink the traditional approach to career development and their attitudes to some groups of managers, e.g., middle managers, who are still overlooked as a source of talents [2].

The migrants are a diverse workforce, and prospective employers pay specific attention to highly skilled ones. This category is constructed artificially, limiting their situation in the labor market [3]. The highly educated international migrants represent a growing segment of the workforce and play a role as an essential source for developing mature economies [4]. So, research analyses drivers for migration and obstacles to integration in the host countries, like determinates of immigration and personnel/human resource practices aimed at the socialization at the workplace. Cebolla-Boado and Miyar-Busto [5] argue that longterm, highly skilled migrants prioritize both investment returns into education and attractive, generous welfare setups.

The skill portfolios of immigrants impact the employment conditions on the host labor markets. Their inflow put pressure to reduce wages of competing native workers (with the similar skills as immigrants possess) and increase of those complementary workers (with skills that complement of skills offered by immigrants [6]. The influence of the intra-EU migrants in the UK, Germany and Denmark was analyzed by Felbo-Kolding, Leschke, and Spreckelsen [7] after the 2004/2007 EU enlargement. They find that it causes a division of labor along occupational and industry lines and determinates wage differences in the mentioned countries, specifically, EU-West/EEA migrants occupy better jobs (even outperforming nationals), followed by EU-South and CEE migrants. Nationals' attitudes in fifteen European countries to migrants show representative surveys before and after the European refugee crisis in 2014. Wealthy natives prefer highly skilled over low-skilled migration irrespective of natives' skill levels [8].

In the world, divergence trends deepen the economic differences among regions and metropolitans, which manifests in many ways, including labor force participation and the spatial distribution of skills and returns to education [9]. Cities in Canada and some advanced economic regions use place branding to attract high-skilled and well-educated immigrants; however, migrants look when they decide the country and places to live more at the economy and housing than traditional branding and promotional efforts [10].

In the case of Central and Eastern countries, the migration expects to continue, and drivers will come from demographic and economic reasons; specifically wage differences between the home and host countries, like Poland or Ukraine, and a perspective of higher earnings in developed economies encourage to transfer $[11,12,13]$. The CEE represents a 
critical labor source region for the tourism and hospitality sectors of many Western countries [14]. The medical professions belong to highly demanding occupations worldwide, particularly in Europe, as the health care sector experiences the most severe labor shortages. Botezat and Ramos [15] analyze the inflow of doctors in the OECD countries from 2000 to 2016 and reveal that the inflow from Central and Eastern Europe (as well as from Africa and Asia) motivates a lower unemployment rate, fair remuneration of physicians, aging population, and the better level of medical technology. The decisive factor for obtaining a highly paid job and social integration of Eastern European migrants becomes the host country's language proficiency, but it does not guarantee employment or career progression [16]. Many high-skilled migrants from the CEE cause structural problems in the domestic labor market. It exists in the health care in the CR, or in Hungary from where emigrants go to the West for altruistic motives to support the household who remain behind [17].

Any worker looking for a job wants to secure himself and his loved ones and integrate into the social community. Career choice traditionally relies on matching a person to job requirements based on a century-old three-step prescriptive formula characterized by a selfexploration, an occupational exploration, and a self-occupation comparison. However, the rapid changes in the labor world destabilized such career choices [18]. The international division of labor, together with modern technology, is changing the conditions for employability and career development. Regardless of the worker is a native and a migrant; anybody must be on the track of a sustainable career and enjoys a moderate degree of productivity, health, and happiness across the lifespan, which means to learn and tackle sustainable career challenges [19].

Baruch [20] comprehensively discusses the scholarly approaches to careers and argues that it is realistic to view career development from a balanced perspective that integrates several points of views:

- a career as an order or chaos,

- boundaryless and protean careers or traditional careers, i.e., gradually climbing a ladder in an organization,

- the organizational or individual perspective in theory development and practical considerations, i.e., who is the agent in developing a career - an organization or an individual,

- meaning of career success: from external to internal to integrated, i.e., who is the crucial evaluator of career success - the external audience or an individual or a combination of both.

These days, it seems that formerly the glorified boundaryless and protean career concepts are over as too agentic. The role of institutions is critical in career sustainability. They manage education and development systems as a part of motivational programs closely reflecting business reality and combine on-the-job training with welfare regimes, worker's voice, rostering, and other benefits [21].

An individual, being in learning mode, creates pre-conditions to facilitate career sustainability [22], mainly if a person can develop critical thinking, problem-solving, communication, and teamwork [23]. In their study, Forrier, De Cuyper, and Akkermans [24] provoke a strong focus on personal agency in employability research and provide arguments that employability is (a) contextual, (b) relational, and (3) polarizing, which stress the importance of the environment, social networks and strategies of organizations to invest in people development. Developing a career must match with an organization's culture where leadership and personnel/HR strategy demonstrate in a shared mindset that learning is a primary mode, at least for surviving and preferably to achieve success. Tordera et al. [25] show no direct relationship exists between HR practices and sustainable careers. They argue that some interactions between age and six HR practices 
influence well-being and performance, i.e., younger employees benefit from staffing, performance appraisal, security, and exit management, but older employees from contingent pay and a competitive salary.

\section{Narrative cases}

\subsection{Narrative case 1}

Radovan, 56, owner of several companies, from which one operates in the ICT sector, and another provides project management services. Clients come from EU countries. His companies belong to small enterprises from the number of employees. So, any business success's crucial resource represents intellectual capital and participative leadership, encouraging staff enthusiasm and engagement.

In the past, he worked as a top manager of banks located in the CR. Based on comparing approaches to career development in large and small companies, he argues that people mostly worked for large employers who planned their careers in the past. Nowadays, the largest employers employ fewer employees in the economy than years ago, and small employers create new jobs. In the future, the workforce is very likely to work for small employers rather than large ones. While large employers will remain a vital part of the economy, small employers will become critical for competitiveness. Job requirements put by small employers include more flexibility and faster adaptation to change.

Radovan has been striving to implement fair personnel practices in his companies. He believes that a reasonable employer must offer a high quality of labor conditions to reduce employees' change jobs. He knows that people seek higher wages and better benefits, want to advance in a career or change a focus in career, enjoy a less stressful job, try to balance work/family life, appreciate opportunities creating an enlargement or an enrichment of employment, need to recognize for accomplishments and have an optimistic boss.

When he established his own business, he gradually delegated all operational functions in personnel management to the managing partner responsible for personnel practices, like, recruitment, selection, performance management, and compensation. The long-term strategy is to pay wages above the local market rates and relay on flexible working hours/self-rostering, but the key indicator of any performance appraisal is sustainable performance. Compensation, together with the work/family-life balance policy, belongs to preferable motives why the staff is willing to work hard, search for learning opportunities and develop hard- and soft competencies as the guarantee of employability.

Career development is based on on-the-job training, as it mostly suits the clients' requirements and achieved results. Participating in projects provides personal development challenges as the most effective learning practice and can increase incentive wages. Becoming a member of international project teams needs to develop critical thinking, teamwork, and communication with diverse clients. However, the Czech educational market is small, so staff must use online training offered by other companies in a network or universities ranked among the world leaders.

He assumes that a life-long career cannot be one-way; it is beneficial for anybody when he/she jumps forward with some falls. A successful career is not just about advancing; in today's flat structures and international involvement in business via ICT, it can develop horizontally, based on expertise, but firmly based on technical skills (digital skills) and the art of dealing with different people. The evaluator of success should be the person himself and the environment in which a worker applies for a job because the contracting authority assesses what added value it will bring for business. He believes that a sustainable career requires positive thinking and endless energy to work on personal competencies. 
Equations should be centred and should be numbered with the number on the right-hand side.

\subsection{Narrative case 2}

Pavel, 57, managing partner, a multinational consultancy firm specialized in human resource development. The company operates in seven European countries and has got five branches outside Europe. The company focuses on corporate training and development, coaching, appraisal interviews, and designing competency models. The Czech subsidiary belongs to the micro-enterprise category, operates here since 1993, and achieves an excellent reputation. It provides services to clients in the CR, Slovakia, and partly in German-speaking countries. The Czech team consists of culturally diverse consultants who speak fluent English and can use an extensive network of freelance consultants. Each subsidiary receives support from the headquarters located in Portugal and utilizes knowhow sharing across borders. They currently suffer from dropping business demands as the consequences of the COVID19. However, they adjust their portfolio of services to match trends in soft training. Some clients, mainly outside the CR, begin to ask for online training and prefer courses in the applications: MS Teams, Google Hangouts, or Webex. The company monitors the education market situation and innovates its procedures to focus on critical thinking, problem-solving, communication, and teamwork. All consultants struggle with an unpleasant form of distance training as they have no face-to-face contacts usually used in practice soft skills. However, they assume as opportunities to combine traditional and online learning with helping clients balancing work-family activities. The career development of consultants must base on a flexible working scheme/self-rostering, home office, diverse teamwork, massive open online courses, and permanently up-graded ICT skills.

A consultant's career demands knowledge, but mainly on personal resilience and a positive approach to change. Any initial success is determined by professional background, e.g., economic, technical, scientific. During a productive life, the consultant is dependent on the ability to adapt, not be afraid to start a new occupation, or change jobs.

\section{Conclusion}

The labor force must learn throughout the whole active life. An idea of a sustainable career always implies to develop competencies matching requirements of the labor market. The starting position represents necessary skills, i.e., literacy, numeracy, foreign languages, and digital skills, and later learn higher skills, like transversal, entrepreneurial, and new digital skills. No one can be sure whether employers welcome the initial education. Some trends in developed economies hint at what job seekers can count on and what to consider when deciding on future education and careers.

The occupations, for which demand is proliferating, offer many career opportunities. They require a university degree and skills development beyond the knowledge acquired at a university. The necessity is upgrading skills with the focus on technical knowledge because new jobs include technology, computers, automation, and artificial intelligence. Many workers will change jobs and careers multiple times during their working lives. These changes are still difficult to define because there is no consensus on what a career change entails and how long a worker should pursue one profession.

In the USA, three of the four fastest-growing occupational groups become the executive, managerial and administrative jobs, specialists and technicians, and their supported occupations. Occupations requiring a low level of formal education will experience stagnation or decline in the employed population due to automation, robotics, 
and the relocation of production to other destinations. Nevertheless, all workers will have employment opportunities as fluctuations occur, and new operations will open. However, those with higher education, being in learning mode and rely on themselves than on the traditional career ladders will get more chances to go ahead.

The paper is supported by the OP Prague - Pole of Growth of the Czech Republic. CZ.07.1.02/0.0/0.0/17_049/0000835. Neurotechnology to Improve the Quality of Life and Cyberbullying Prevention in Society 4.0. CTU in Prague, FBME. Period: 1.2.2019 - 31. 7.2021.

\section{References}

1. Oesch, D., Piccitto, G. (2019). The polarization myth: Occupational upgrading in Germany, Spain, Sweden, and the UK, 1992-2015. Work and Occupations, 46(4), 441469.

2. Whysall, Z., Owtram, M., Brittain, S. (2019). The new talent management challenges of Industry 4.0. Journal of Management Development, 38(2), 118-129.

3. Sandoz, L. (2020). Understanding access to the labour market through migration channels. Journal of Ethnic and Migration Studies, 46(1), 222-241.

4. Tharenou, P., Kulik, C.T. (2020). Skilled migrants employed in developed, mature economies: from newcomers to organizational insiders. Journal of Management, 46(6), 1156-1181.

5. Cebolla-Boado, H., Miyar-Busto, M. (2020). Are they deterred by welfare? Digging into the drivers of highly skilled temporary and long-term migrants in Europe. International Migration, 58(2), 180-204.

6. Edo, A. (2019). The impact of immigration on the labor market. Journal of Economic Surveys, 33(3), 922-948.

7. Felbo-Kolding, J., Leschke, J., Spreckelsen, T.F. (2019). A division of labour? Labour market segmentation by region of origin: the case of intra-EU migrants in the UK, Germany, and Denmark. Journal of Ethnic and Migration Studies, 45(15), 2820-2843.

8. Naumann, E., Stoetzer, L.F., Pietrantuono, G. (2018). Attitudes towards highly skilled and low-skilled immigration in Europe: A survey experiment in 15 European countries. European Journal of Political Research, 57(4), 1009-1030.

9. Storper, M. (2018). Separate worlds? Explaining the current wave of regional economic polarization. Journal of Economic Geography, 18(2), 247-270.

10. Cleave, E., Arku, G. (2020). Immigrant attraction through place branding? Evidence of city-level effectiveness from Canada's London. Cities, 97, UNSP 102502.

11. Bite, P., Szombathelyi, M.K., Vasa, L. (2020). The concept of labour migration from the perspective of Central and Eastern Europe. Economics \& Sociology, 13(1), 197216.

12. Jancewicz, B., Markowski, S. (2019). Economic turbulence and labour migrants' mobility intentions: polish migrants in the United Kingdom, Ireland, the Netherlands and Germany 2009-2016. Journal of Ethnic and Migration Studies, n/a(n/a).

13. Libanova, E. (2019). Labour migration from Ukraine: Key features, drivers and impact. Economics \& Sociology, 12(1), 313-328.

14. Filimonau, V., Mika, M. (2019). Return labour migration: an exploratory study of Polish migrant workers from the UK hospitality industry. Current Issues in Tourism, 22(3), 357-378.

15. Botezat, A., Ramos, R. (2020). Physicians' brain drain - a gravity model of migration flows. Globalization and Health, 16(1), article number 7. 
16. Dickey, H., Drinkwater, S., Shubin, S. (2018). Labour market and social integration of Eastern European migrants in Scotland and Portugal. Environment and Planning A: Economy and Space, 50(6), 1250-1268.

17. Kajdi, L., Ligeti, A.S. (2020). Remittance behaviour of intra-EU migrants - evidence from Hungary. Comparative Populations Studies, 45, 87-113.

18. Lent, R.W., Brown, S.D. (2020). Career decision making, fast and slow: Toward an integrative model of intervention for sustainable career choice. Journal of Vocational Behavior, 120, UNSP 103448.

19. Heslin, P.A., Keating, L.A., Ashford, S.J. (2020). How being in learning mode may enable a sustainable career across the lifespan. Journal of Vocational Behavior, 117(SI), UNSP 103324.

20. Baruch, J. (2006). Career development in organizations and beyond: Balancing traditional and contemporary viewpoints. Human Resource Management Review, 16, 125-138.

21. Tomlinson, J., Baird, M., Berg, P., Cooper, R. (2018 Jan). Flexible careers across the life course: Advancing theory, research and practice. Human Relations, 71(1), 4-22.

22. Van der Heijden, B., De Vos, A., Akkermans, J., Spurk, D., Semeijn, J., Van der Velde, M., Fugate, M. (2020). Sustainable careers across the lifespan: Moving the field forward. Journal of Vocational Behavior, 117, 103344.

23. Rampersad, G. (2020). Robot will take your job: Innovation for an era of artificial intelligence. Journal of Business Research, 116, 68-74.

24. Forrier, A., De Cuyper, N., Akkermans, J. (2018). The winner takes it all, the loser has to fall: Provoking the agency perspective in employability research. Human Resource Management Journal, 28(4), 511-523.

25. Tordera, N., Peiro, J.M., Ayala, Y., Villajos, E., Truxillo, D. (2020). The lagged influence of organizations' human resources practices on employees' career sustainability: The moderation role of age. Journal of Vocational Behavior, 120, article number UNSP 103444. 